\title{
Enzyme-linked immunosorbent assay for measurement of antibody against cytomegalovirus and rubella virus in a single serum dilution
}

\author{
AM VAN LOON, JThM VAN DER LOGT, J VAN DER VEEN \\ From the Department of Medical Microbiology, University of Nijmegen, $6500 \mathrm{HB}$ Nijmegen, \\ The Netherlands
}

SUMMARY Enzyme-linked immunosorbent assays (ELISA) were developed for quantifying cytomegalovirus (CMV) and rubella antibodies using a single serum dilution (1/800) in conjunction with a standard curve. A near linear relation was found between the logarithms of absorbance values of sera at a dilution of 1/800 and the titres as determined by an end point dilution ELISA. The reproducibility of the single dilution ELISA was good; the within-test coefficients of variation averaged $7.5 \%$ for CMV antibody and $12.4 \%$ for rubella antibody. A close correlation was found between ELISA and complement-fixing (CF) antibody titres to CMV and between ELISA and haemagglutination-inhibition (HI) antibody titres to rubella virus. The titres in ELISA were 200 to 1000 times higher than in CF for CMV and 50 to 100 times higher than in HI for rubella virus.

Many reports have described the application of the enzyme-linked immunosorbent assay (ELISA) for laboratory diagnosis of infectious diseases. ${ }^{12}$ With respect to sensitivity, specificity, reproducibility, and ease of performance, ELISA has distinct advantages over existing techniques for determining antibody titres to different aetiological agents including cytomegalovirus (CMV) ${ }^{3-6}$ and rubella virus. ${ }^{3}$ 7-10 CMV and rubella antibody levels in ELISA have been determined by examining serial serum dilutions $s^{4} 6 \quad 7 \quad 10$ or a single serum dilution. ${ }^{358}$ It is apparent from these studies that there is a need to standardise methods to distinguish between specific and nonspecific reactivity.

We report an ELISA procedure which permits a precise and reproducible quantification of CMV and rubella antibodies by examination of a single serum dilution in conjunction with a standard curve. The sensitivity of the test is compared with that of complement fixation (CF) for CMV and haemagglutination inhibition (HI) for rubella virus.

\section{Material and methods}

\section{ANTIGENS}

The AD-169 strain of CMV was used. For ELISA

Accepted for publication 9 October 1980 a nuclear antigen was prepared from CMV-infected human diploid fibroblasts essentially according to the procedure described previously. ${ }^{11} 12$ The optimal antigen dilution in ELISA as determined by block titration $^{13}$ was $1 / 100$. Control nuclear antigen for CMV was prepared in a similar way from uninfected cells. The protein content of CMV and control nuclear antigens as determined by the Lowry method was approximately $0.4 \mathrm{mg} / \mathrm{ml}$. CMV antigen for the CF titres was prepared by glycine extraction of CMVinfected human diploid fibroblasts. ${ }^{14}$

The Gilchrist strain of rubella virus was used to prepare antigen for ELISA. Virus was grown in Vero cells ${ }^{15}$ and purified using a combination of ultrafiltration and discontinuous sucrose gradient centrifugation. The protein content of the antigen was approximately $0.3 \mathrm{mg} / \mathrm{ml}$. The optimal antigen dilution for ELISA was $1 / 100$. Control antigen for rubella virus was prepared from a suspension of uninfected Vero cells in phosphate-buffered saline (PBS) at $\mathrm{pH} 7.4$ by sonication and subsequent clarification at low speed centrifugation.

CF AND HI TESTS

The CF test procedure was the microtitre technique described by Casey. ${ }^{16}$ The HI test was performed according to the technique of Stewart et al. ${ }^{17}$ using pigeon erythrocytes and a commercial rubella virus antigen (Behringwerke AG, Marburg). Sera were 65 
treated with $\mathrm{MnCl}_{2}$-heparin ${ }^{18}$ to remove non-specific haemagglutination inhibitors.

SERUM SAMPLES

Sera submitted for rubella screening from hospital personnel and pregnant women and sera from patients clinically suspected for rubella or CMV infection were available. The sera were stored at $-20^{\circ} \mathrm{C}$ for several weeks before testing by ELISA.

\section{ELISA PROCEDURE}

The test was performed essentially as described previously. ${ }^{131920}$ In the end point dilution ELISA serial twofold dilutions of serum $(0.1 \mathrm{ml}$ per well) were incubated at $37^{\circ} \mathrm{C}$ for 2 hours in antigen-coated plates using PBS-Tween $(0.05 \%)$ with $2 \%$ fetal bovine serum as diluent for tests with CMV and PBS-Tween (0.1\%) with $10 \%$ calf serum and rubella control antigen at a concentration of $0.1 \mathrm{mg} / \mathrm{ml}$ as diluent for tests with rubella virus. In the single dilution ELISA $0.1 \mathrm{ml}$ of $1 / 800$ diluted serum was added to each of two antigen-coated wells. Conjugate (commercial peroxidase-conjugated anti-human immunoglobulin G, $\gamma$ chain-specific, Institut Pasteur, Paris) diluted $1 / 1000$ in PBS-Tween $(0.05 \%)$ with $2 \%$ fetal bovine serum was used for tests with CMV and conjugate diluted $1 / 5000$ in PBS-Tween (0.1\%) with $10 \%$ calf serum was used for tests with rubella virus. After addition of substrate solution and $\mathbf{3 0}$ minutes' incubation, the colour intensity was determined by spectrophotometry (Vitatron DCP); the results were expressed as the absorbance at $492 \mathrm{~nm}$.

\section{DETERMINATION OF ANTIBODY TITRES}

IN ELISA

To determine antibody titres by end point dilution the absorbance value of each serum dilution was compared with that of the same dilution of the negative control serum examined in the same plate. The titre of a patient's serum to CMV or rubella was considered to be the dilution with an absorbance value which was 1.7 and 2.5 times, respectively, the absorbance value of the corresponding dilution of the negative control sera for the two viruses. The end point was calculated by interpolation with readings at succeeding serum dilutions. The rationale of this approach will be presented in the first section of results.

Antibody titres in the single dilution ELISA were calculated from the mean value of the duplicate tests with a 1/800 diluted patient's serum in conjunction with a standard curve. Serum pools with varying titres were used to construct standard curves. A standard curve for CMV was obtained by plotting the absorbance values of each serum pool examined at a dilution of $1 / 800$ against its antibody titre as previously determined by the end point dilution test. $\frac{0}{\overrightarrow{2}}$ A standard curve for rubella virus was constructed by plotting "specific absorbance" values against $\vec{\Rightarrow}$

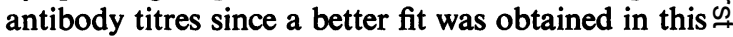
way. "Specific absorbance" values were obtained by을 subtracting the absorbance of the $1 / 800$ diluted negative control serum from the absorbance of each $\frac{\bar{\sigma}}{\bar{\phi}}$ serum pool.

\section{Results}

DETERMINATION OF ANTIBODY TITRES BY END POINT DILUTION ELISA

Fig. 1 compares the dose response relation of sera with varying antibody levels to CMV (a) and $\omega$ rubella virus (b) with that of negative sera. Intercepts $\dot{\circ}$ with the dashed line representing the mean negative 8 value of each dilution plus three standard deviations $\mathrm{F}$

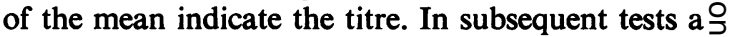
negative control serum consisting of a pool of negative sera was used for determining positive $/ \subseteq$ negative cut-off values. An absorbance value 1.7 and $\underset{\Phi}{\bar{D}}$ 2.5 times the absorbance of the negative control $\overrightarrow{0}$ serum corresponded with the mean value of negative $\stackrel{\circ}{-}$ sera plus three standard deviations of the mean for ${ }^{-}$ CMV and rubella virus, respectively. Since theo absorbances of a large number of negative sera were found to have a nearly normal distribution in both tests (data not shown) it may be calculated that the $\frac{\partial}{8}$ probability of obtaining a false positive result is less $\stackrel{D}{2}$ than $0.5 \%$ in tests with both viruses.

\section{REPRODUCIBILITY}

Four replicates of a positive serum and the negative control serum for CMV and rubella virus were examined at a dilution of $1 / 100$ in consecutive tests:(Table).

DETERMINATION OF ANTIBODY TITRE BY SINGLE DILUTION ELISA

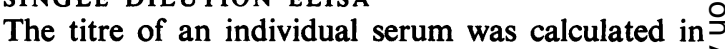
conjunction with a standard curve constructed for $\stackrel{7}{0}$ each plate similar to the experiment depicted in the inserts of Fig. 1. Linear regression coefficients of $\tilde{N}$ standard curves exceeded 0.98. Comparison of the $\mathrm{N}$ absorbance values of a single dilution (1/800) and end point dilution titres of 77 rubella sera provided ${ }^{\mathrm{\omega}}$ evidence of the validity of using a single dilution (Fig. 2).

COMPARISON WITH CF FOR CMV ANTIBODY AND HI FOR RUBELLA ANTIBODY

Fig. 3 shows that the single dilution ELISA was more $\frac{\vec{D}}{\mathbb{D}}$ sensitive than the CF test for detecting CMV anti- $\frac{\rho}{\Phi}$ body. Antibody titres in ELISA increased pro- 2 portionally with increasing CF titres; Spearman's 


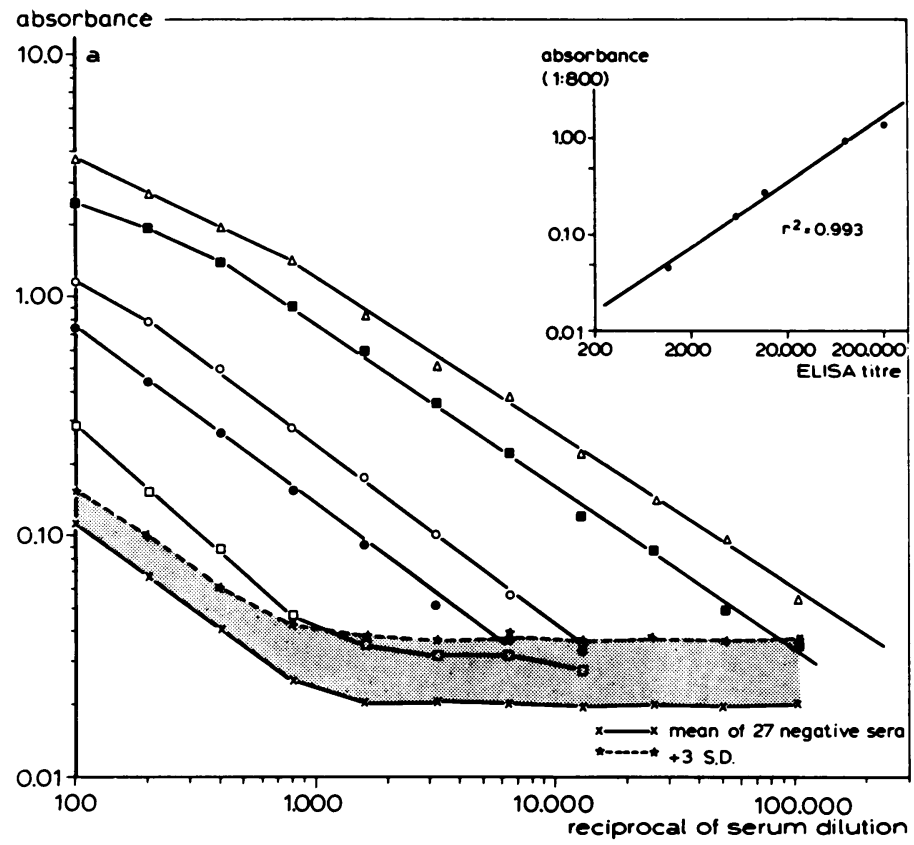

Fig. 1 End point dilution ELISA for antibody to $C M V($ top, a) and rubella virus (below, $b$ ) using five positive and 27 negative human sera in each assay. The lower line represents the mean absorbance values of the negative sera. The broken line denotes the values three

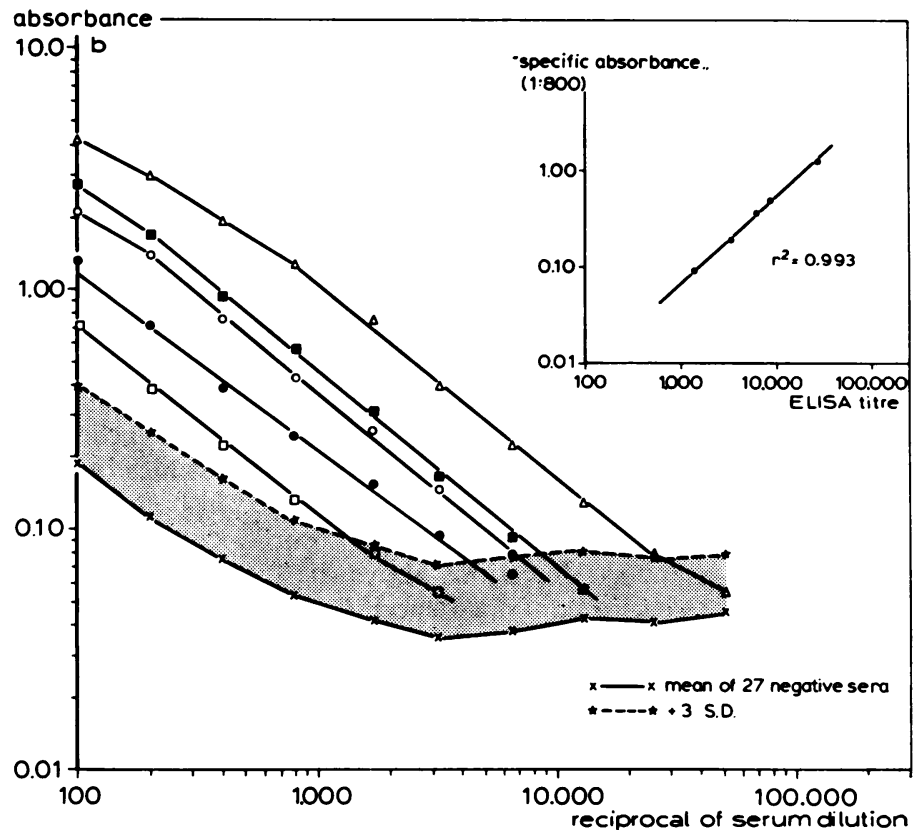
standard deviations above these means. The inserts show the relation between antibody titres of the positive sera and their absorbance at a 1/800 dilution.

Reproducibility of enzyme-linked immunosorbent assays (ELISA) for antibody to cytomegalovirus (CMV) and rubella virus

\begin{tabular}{|c|c|c|c|c|}
\hline \multirow[t]{2}{*}{ Antibody } & \multicolumn{2}{|l|}{ Within-test * } & \multicolumn{2}{|l|}{ Between-test $\dagger$} \\
\hline & +ve serum & - ve serum & +ve serum & - ve serum \\
\hline $\begin{array}{l}\text { Cytomegalovirus } \\
\text { Rubella virus }\end{array}$ & $\begin{array}{l}5 \cdot 3 \%(1 \cdot 5-9 \cdot 8) \\
6 \cdot 4 \%(4 \cdot 0-7 \cdot 0)\end{array}$ & $\begin{array}{r}7 \cdot 5 \%(4 \cdot 0-13 \cdot 2) \\
12 \cdot 4 \%(9 \cdot 0-20 \cdot 0)\end{array}$ & $\begin{array}{l}1 \cdot 18(1 \cdot 01-1 \cdot 40) \\
1 \cdot 30(0.98-1 \cdot 85)\end{array}$ & $\begin{array}{l}0.13(0.09-0.17) \\
0.08(0.05-0.12)\end{array}$ \\
\hline
\end{tabular}

* Mean variation coefficient and range. Four replicates of each serum were examined in seven different tests for CMV and five different tests for rubella virus by single dilution ELISA.

† Mean absorbance and range in these tests. 


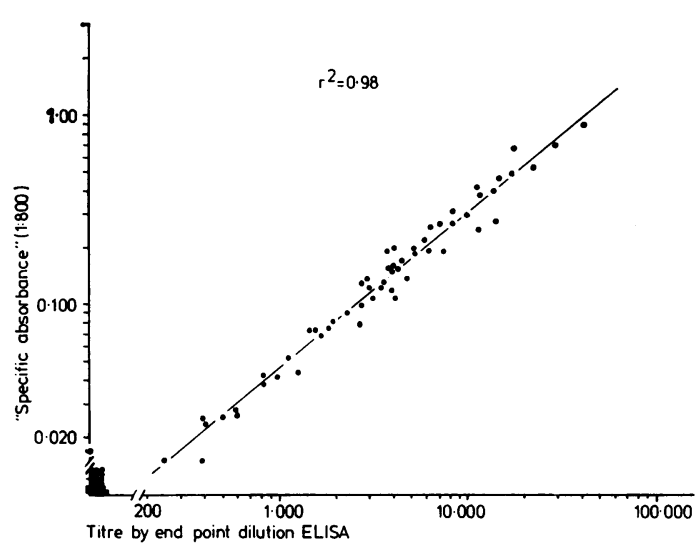

Fig. 2 Relation between antibody titres of 77 sera to rubella virus as determined by end point dilution ELISA and their absorbance at a 1/800 dilution.

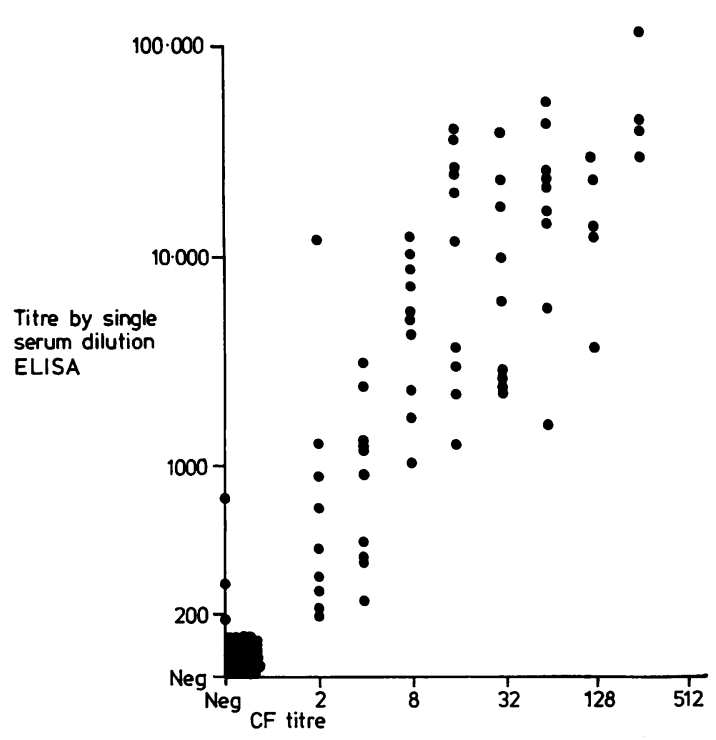

Fig. 3 Comparison of CMV antibody titres of 113 sera determined by single dilution ELISA and the CF test.

rank correlation coefficient $\left(r_{s}\right)$ was $0.88(p<0.001)$. Titres in ELISA were approximately 200 to 1000 times higher than in CF titres.

As seen in Fig. 4, similar results were obtained when sera were examined by ELISA and the HI test for rubella antibody $\left(r_{s}=0.94, p<0.001\right)$. Antibody titres in ELISA were approximately 50 to 100 times higher than in HI titres.

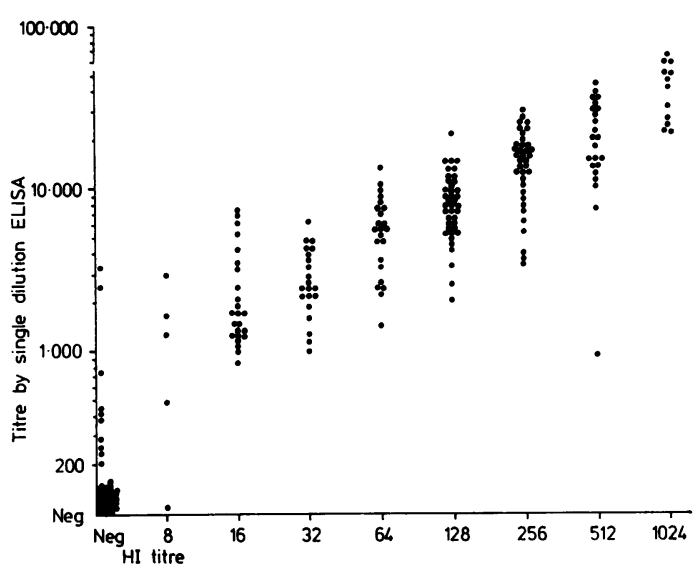

Fig. 4 Comparison of rubella antibody titres of 231 sera determined by single dilution ELISA and the HI test.

\section{Discussion}

One of the main problems in developing ELISA is to distinguish between low levels of specific reactivity and non-specific reactivity. The use of a predetermined fixed cut-off level as described by other investigators 351021 does not take into account dayto-day variation and decrease of non-specific reac- ̊ tivity when sera are further diluted. This will hamper $\mathbb{Q}$ standardisation of the test and will cause a relative $\vec{\overrightarrow{ }}$ underestimation of high antibody titres. A better 3 procedure is to determine the cut-off level from the frequency distribution of the absorbance values of negative sera. ${ }^{1922-24}$ Since in accordance with previous reports 2223 the absorbance values of nega- ? tive sera were normally distributed in both tests, we assumed that sera with absorbance values three standard deviations above the mean value of negative sera contained specific antibody. If absorbance values of negative sera are not normally distributed other statistical methods (transformation, non- $\rightarrow$ parametric methods) should be used to establish a cut-off level. ${ }^{24}$

In ELISA for CMV antibody the use of control antigen 4625 was found to be unnecessary since none $O$ of the 113 sera tested showed a significantly increased $\underset{\omega}{ }$ reactivity in wells coated with control antigen. In contrast, the use of control antigen was required inco ELISA for rubella antibody since some sera showed $\bar{\Phi}$ an increased nonspecific reactivity in wells coated $\stackrel{?}{+}$ with control antigen. ELISA for rubella antibody $\frac{T}{T}$ was more practical, economical, and precise when $\stackrel{\vec{D}}{\circ}$ sera were diluted in buffer solution containing con- $\stackrel{?}{\stackrel{P}{Q}}$ trol antigen compared with the use of control $\stackrel{\square}{\square}$ antigen-coated wells as described by other investi- -0 
gators. ${ }^{81021}$ Purification of the rubella virus antigen further reduced non-specific reactivity. ${ }^{7910}$

There was a linear relation between logarithms of antibody levels and absorbance values over a wide range of serum dilutions as has been reported previously for other antigen antibody systems. ${ }^{19} 242627$ Furthermore, the slopes of the linear portions of dose response curves of six CMV and eight rubella acutephase sera (data not shown) appeared to be approximately the same as those of the late-convalescent sera depicted in Fig. 1. These data indicate that antibody titres could be reliably determined by examining only a single (1/800) serum dilution in conjunction with a standard curve. An advantage of using a high dilution is that complications due to saturation phenomena or to the presence of other immunoglobulin classes are avoided. ${ }^{24}$ Furthermore, it allows for detection of antibody in very small sample volumes. When the problems related to the presentation of ELISA results ${ }^{24}$ are sufficiently solved, we expect that ELISA will rapidly become a generally accepted procedure in routine serodiagnosis.

We are indebted to Ria Heeren, Tini Tangelder, and Els Thissen for their skilful technical assistance and Marij Gielen and Dr F Heessen for preparing the CMV antigen.

\section{References}

${ }^{1}$ Voller A, Bartlett A, Bidwell DE. Enzyme immunoassays with special reference to ELISA techniques. J Clin Pathol $1978 ; 31: 507-20$

2 O'Beirne A, Cooper HR. Heterogenous enzyme immunoassay. J Histochem Cytochem 1979;27:1148-62.

${ }^{3}$ Voller A, Bidwell DE. Enzyme-immunoassays for antibodies in measles, cytomegalovirus infections and after rubella vaccination. Br J Exp Pathol 1976;57:243-7.

4 Castellano GA, Hazzard GT, Madden DL, Sever JL. Comparison of the enzyme-linked immunosorbent assay and the indirect hemagglutination test for detection of antibody to cytomegalovirus. J Infect Dis 1977;136:337410.

${ }^{5}$ Booth JC, Hannington G, Aziz TAG, Stern H. Comparison of enzyme-linked immunosorbent assay (ELISA) technique and complement-fixation test for estimation of cytomegalovirus IgG antibody. J Clin Pathol 1979;32: 122-7.

- Sarov I, Andersen P, Andersen HK. Enzyme-linked immunosorbent assay (ELISA) for determination of IgG antibodies to human cytomegalovirus. Acta Pathol Microbiol Scand [B] 1980;88:1-9.

7 Gravell M, Dorsett PH, Gutenson O, Ley AC. Detection of antibody to rubella virus by enzyme-linked immunosorbent assay. $J$ Infect Dis 1977;136:S300-303.

${ }^{8}$ Vejtorp M. Enzyme-linked immunosorbent assay for determination of rubella IgG antibodies. Acta Pathol Microbiol Scand [B] 1978;86:387-92.

9 Leinikki PO, Shekarchi I, Dorsett P, Sever JL. Enzymelinked immunosorbent assay determination of specific rubella antibody levels in micrograms of immunoglobulin $\mathbf{G}$ per milliliter of serum in clinical samples. J Clin Microbiol 1978;8:419-23.
${ }^{10}$ Forghani B, Schmidt NJ. Antigen requirements, sensitivity, and specificity of enzyme immunoassays for measles and rubella viral antibodies. J Clin Microbiol 1979;9:657-64.

${ }^{11}$ Schmitz H, Doerr HW, Kampa D, Vogt A. Solid-phase enzyme immunoassay for immunoglobulin $\mathbf{M}$ antibodies to cytomegalovirus. J Clin Microbiol 1977;5:629-34.

${ }^{12}$ Stagno S, Reynolds DW, Smith RJ. Use of isolated nuclei in the indirect fluorescent-antibody test for human cytomegalovirus infection: Comparison with microneutralization, anticomplement, and conventional indirect fluorescent-antibody assay. J Clin Microbiol 1978; 7:486-9.

${ }^{13}$ Voller A, Bidwell DE, Bartlett A. Microplate enzyme immunoassays for the immunodiagnosis of viral infections. In: Rose NR, Friedman $\mathrm{H}$, eds. Manual of Clinical Immunology. Washington DC: American Society for Microbiology, 1976.

${ }^{14}$ Kettering JD, Schmidt NJ, Lennette EH. Improved glycine-extracted complement-fixing antigen for human cytomegalovirus. J Clin Microbiol 1977;6:647-9.

${ }^{15}$ Liebhaber H, Pajot T, Riordan JT. Growth of high-titered rubella virus in roller bottle cultures of Vero-cells. Proc Soc Exp Biol Med 1969;130:12-14.

${ }^{16}$ Casey HL. II Adaptation of LBCF-method to microtechnique. In: Standardized diagnostic complementfixation and adaptation to microtest. US Public Health Monograph No. 74, 1965.

${ }^{17}$ Stewart GL, Parkman PD, Hopps HE, Douglas RD, Hamilton ID, Meyer HM Jr. Rubella virus hemagglutination inhibition test. $N$ Engl J Med 1967;276:554-7.

18 Cooper IZ, Matters B, Rosenblum JK, Krugman S. Experience with a modified rubella hemagglutination inhibition antibody assay. JAMA 1969;207:89-93.

19 van Loon AM, van der Veen J. Enzyme-linked immunosorbent assay for quantitation of toxoplasma antibodies in human sera. J Clin Pathol 1980;33:635-9.

${ }^{20}$ van Loon AM, van der Logt JThM, van der Veen J. Evaluation of commercial ELISA tests. Lancet 1980; : 319-20.

${ }^{21}$ Morgan-Capner P, Pullen HJM, Pattison JR, Bidwell DE, Bartlett A, Voller A. A comparison of three tests for rubella antibody screening. J Clin Pathol 1979;32:542-5.

22 Bishai FR, Galli R. Enzyme-linked immunosorbent assay for detection of antibodies to influenza $A$ and $B$ and parainfluenza type 1 in sera of patients. J Clin Microbiol 1978;8:648-56.

${ }^{23}$ Vejtorp M, Fanøe E, Leerhoy J. Diagnosis of postnatal rubella by the enzyme-linked immunosorbent assay for rubella IgM and IgG antibodies. Acta Pathol Microbiol Scand $[B]$ 1979;87:155-60.

24 de Savigny D, Voller A. The communication of ELISA data from laboratory to clinician. Journal of Immunoassay 1980;1:105-28.

25 Cappel R, de Cuyper F, Braekeleer J. Rapid detection of IgG and IgM antibodies for cytomegalovirus by the enzyme linked immunosorbent assay (ELISA). Arch Virol $1978 ; 58: 253-8$

28 Parker JC, O'Beirne AJ, Collins MJ. Sensitivity of enzyme linked immunosorbent assay, complement-fixation, and hemagglutination inhibition serological tests for detection of Sendai virus antibody in laboratory mice. $J$ Clin Microbiol 1979;9:444-7.

27 Gerber MA, Gray ED, Ferrieri P, Kaplan EL. Enzymelinked immunosorbent assay for antibodies in human sera to streptococcal DNase. J Lab Clin Med 1980;95: 258-65.

Requests for reprints to: Dr AM van Loon, Department of Medical Microbiology, Geert Grooteplein Zuid 24, 6500 HB Nijmegen, The Netherlands. 